\title{
ETHICAL ISSUES IN MARKETING: AN APPLICATION FOR UNDERSTANDING ETHICAL DECISION MAKING
}

\author{
Nurettin PARILTI*, Banu KÜLTER DEMİRG̈̈NEŞ **, \\ Bülent ÖZSAÇMACI $* * *$
}

\begin{abstract}
In recent years business ethics and social responsibility have gained great importance in marketing practices, especially in societal marketing practices. Businesses infinitely struggle to indicate their contributions to society. Consumers consciously evaluate this contribution. Manipulated consumer choices and unethical marketing applications can affect purchasing behavior. Particularly intense competition, globalization and societal consciousness transform businesses into social organizations and lead them into marketing efforts offering social value. Although business ethics and social responsibility of businesses have gained more attention in recent years, defining consumers' perceptions on ethical issues is still minimal. This study presents an empirical research of consumer perceptions on ethical issues. Reflection of this perception on purchasing behavior is also another important issue to be considered.

The aim of this study is to investigate the factors related with ethical issues in marketing practices and to reveal possible influences of these factors on consumers' ethical decision making. The main objective of the study is to find out consumers' perceptions on businesses' ethical issues such as misleading advertising, deceptive packaging and to reveal the impact of these issues on their ethical purchasing behavior or ethical decision making. It also reveals which criteria is more important for ethical decision making.

This study reveals that consumers reflect their ethical perceptions on their purchasing behavior. Each ethical issue has been found to be a positive effect on purchasing behavior. Businesses' practices on packaging has been indicated as the most effective ethical issue on purchasing behavior. The study is considered to be a significant outcome for businesses to direct their advertising, packaging and other activities.

Prof. Dr. Gazi University, Faculty of Economics and Administrative Sciences, Department of Management.www.nurettinparilti@gmail.com

** Assistant Prof. Ahi Evran University, Faculty of Economics and Administrative Sciences, Department of Management. www.banukulter2000@yahoo.com

*** Assistant Prof. Çankaya University, Department of Foreign Trade. www.bozsacmaci@cankaya.edu.tr
\end{abstract}


Keywords: Marketing Ethic, Social Responsibility, Purchasing Behavior.

JEL Classification: M14, M31.

\section{PAZARLAMADA ETIKK KONULAR: ETIKK KARAR ALMA ÜZERİNE BİR UYGULAMA}

\section{$\ddot{O} z e t$}

Son yıllarda işletme etiği ve sosyal sorumluluk kavramları pazarlama alanında özellikle de sosyal pazarlama faaliyetlerinde büyük önem kazanmıştır. Issletmeler, topluma yönelik çabalarını göstermek için büyük bir uğraş vermektedirler. Tüketiciler ise söz konusu çabalarl ve katkıları bilinçli olarak değerlendirmektedirler. Manipüle edilmiş tüketici tercihleri ve etik olmayan pazarlama uygulamalarl, tüketicilerin satın alma davranışını etkileyebilmektedir. Özellikle yoğun rekabet, küreselleşme ve sosyal bilinçlenme, işletmeleri birer sosyal örgüt konumuna dönüştürmekte ve sosyal değer sunan pazarlama çabalarına öncülük etmektedir. Son yılarda işletmelerin etik ve sosyal sorumlulukları önem kazanmasına răgmen, tüketicilerin etik konular ile ilgili algılarını tanımlamak konusunda eksiklikler söz konusudur. Bu çalışma, tüketicilerin etik konular ile ilgili algılarını deneysel bir şekilde sunmaktadır. Söz konusu algının, satın alma davranışına yansıması ise düşünülmesi gereken bir diğer önemli unsurdur.

$\mathrm{Bu}$ çalışmanın amacı, işletmenin pazarlama faaliyetlerinde, etik konusu ile ilgili olabilecek faktörleri belirterek, söz konusu faktörlerin tüketicilerin etik karar verme sürecindeki olası etkilerini ortaya koymaktır. Tüketicilerin aldatıcı (yanıltıcı) reklam, aldatıcı paketleme, gibi konularda algılarını ögrenmek ve bu meselelerin onların satın alma davranışlarında ya da etik karar verme süreçlerinde etkisini tespit etmek amaçlanmaktadır. Çalışma aynı zamanda hangi unsurun etik karar vermede daha önemli olduğunu ortaya koymaktadır.

Çalışmanın sonucunda tüketicilerin etik konulara yönelik algılarını, satın alma davranıslarına yansıttıkları ortaya çıkmaktadır. Her bir etik meselenin satın alma davranışı üzerinde pozitif bir etkisi söz konusudur. Issletmelerin paketleme faaliyetleri konusundaki uygulamaları satın alma davranışı üzerinde en etkili unsur olmaktadır. Çalışmanın işletmelere reklam, paketleme, çevreyi ve tüketiciyi önemseme gibi konularda yol gösterebilece ği düşünülmektedir.

Anahtar kelimeler: Pazarlama Etiği, Sosyal Sorumluluk, Satın Alma Davranışl.

JEL Sınıflaması: M14, M31.

\section{Introduction}

Marketing management is an art and science of choosing target markets and getting, keeping and growing customers through creating, delivering, and communi- 
cating superior customer value ${ }^{1}$. From this definition we can say that the concept of customer value settled to the center of the contemporary marketing efforts. According to American Marketing Association (AMA), value represents the collective conception of what communities find desirable, important and morally proper. Companies should specifically include a conscious attempt about relating moral principles to all their business practices by the means of dealing and caring about all its stakeholders (customers, employees, suppliers and, local communities) as a result of ethical behavior and social responsibility.

In the modern economic environment companies are stressed with the communication practices to make sure that customers get the accurate marketing message. Some of the companies may attempt unethical ways (e.g. producing low quality products, unfair pricing, misleading advertising, deceptive packaging) to take the lead in the competition challenge and influence consumers' purchasing behavior to gather a bigger piece from the market share. The concept of consumerism takes place as a social force to protect consumer interests in the marketplace by organizing consumer pressures on business ${ }^{2}$. Consumerism is the public demand both for refinement in marketing practices to make them more informative, more responsive, more sincere, more truthful and more efficient, and for a new concern with factors other than privately consumed goods and services that determine the quality of life ${ }^{3}$.

On the other hand, a growing number of customers are becoming aware of the ethical implications of the products they buy and are adapting their purchasing behavior accordingly ${ }^{4}$. Ethical consumer behavior is a popular concept, which can be described as 'decision-making, purchases and other consumption experiences that are affected by the consumer's ethical concerns ${ }^{5}$. Through ethical concerns, consumers can communicate their attitudes or perceptions towards companies or marketing practitioners into expressed purchasing decisions. A socially-responsible company will surely care about customers, employees, suppliers, the local community, society, and the environment.

The overall objective of this study is to investigate factors related with business ethics and to reveal possible influences of these factors on consumers' ethical deci-

1 M. Ahmad, et.al. "Ethical Evaluation of Pharmaceutical Marketing in Pakistan", Acta Bioethica, 17(2), 2011, pp. 215-224.

2 H. Ismail and M.F.A.K. Panni, "Consumers Perceptions on the Consumerism Issues and Their Influence on Their Purchasing Behavior: A View from Malaysian Food Industry", Journal of Legal, Ethical and Regulatory Issues, 11(1), 2008, pp. 43-64.

3 S.A. Sherlaker, Marketing Management, (6th ed). Himalaya Publishing House, 1999.

4 R. Harrison et.al. The Ethical Consumer, London: Sage Publications, 2005; T. Mason, "The Importance of Being Ethical", Marketing, 2000, pp. 27; P.J. McGoldrick, and O.M. Freestone, "Ethical Product Premiums: Antecedents and Extent of Consumers' Willingness to Pay", International Review of Retail, Distribution and Consumer Research, 18(2), 2008, pp. 185-201.

5 E. Cooper-Martin and M.B. Holbrook, "Ethical Consumption Experiences and Ethical Space" Advances in Consumer Research, 20, 1993, pp. 113-118. 
sion making. The main objective of the study is to find out consumers' perceptions on businesses' ethical issues such as misleading advertising, unfair pricing, deceptive packaging, caring about consumers and environmental issues and to reveal the impact of these issues on their ethical purchasing behavior or ethical decision making.

\section{Literature Review}

When a marketing practitioner or a scholar interested with marketing ethics, at least they need to know about Corporate Social Responsibility (CSR), ethical issues in marketing, ethical decision making process, and ethical purchasing behavior and consumerism concepts. In the following sections related with literature review, authors will explain about each aspect in length.

\subsection{Business Ethics}

Both marketing practitioners and scholars approach ethics concept from different perspectives. One perspective is that ethics is about being moral individual and personal values which are the key elements to ethical decisions in marketing. Ethical features such as honesty, fairness, responsibility, and citizenship are assumed to be values that can guide complex marketing decisions in the context of an organization. On the other hand, approaching ethics from an organizational perspective assumes that establishing organizational values, codes, and training is necessary to provide consistent and shared approaches to making ethical decisions ${ }^{6}$. Kotler $(1997)^{7}$ approached this subject from a different point of view (best long-term interests of consumers and society) and called as, "societal marketing". According to Kotler, marketers should build social and ethical considerations into their marketing practices.

Ethics has been termed the study and philosophy of human conduct, with an emphasis on the determination of right and wrong. For marketers, ethics in the workplace refers to rules (standards, principles) governing the conduct of organizational members and the consequences of marketing decisions ${ }^{8}$. Ethics is defined as an inquiry into the nature and grounds of morality where morality means moral judgments, standards, and rules of conduct ${ }^{9}$. Murphy et al., (2005) ${ }^{10}$ mentioned ethical marketing as, practices that emphasize transparent, trustworthy, and responsible personal and

$6 \quad$ O.C. Ferrell and L. Ferrell, "Ethics and Marketing Education." Marketing Education Review, 14 (3), 2005, pp. 71-79.

7 Philip Kotler, Marketing Management: Analysis, Planning, Implementation and Control, 9th ed., Prentice Hall, Inc., Englewood Cliffs, NJ. 1997.

8 O.C. Ferrell, "A Framework for Understanding Organizational Ethics: New Challenges for Business Schools and Corporate Leaders". R.A. Peterson and O.C. Ferrell, (eds.) Armonk, New York: M.E. Sharpe, 2005, pp. 3-17.

9 J. Tsalikis and D. Fritzsch, "Business Ethics: A Literature Review with a Focus on Marketing Ethics" Journal of Business Ethics, 8(2), 1989, pp. 695-743.

10 Patrick E. Murphy et.al. Ethical Marketing, Upper Saddle River, NJ: Pearson Education, 2005. 
organizational marketing policies and actions that exhibit integrity as well as fairness to consumers and other stakeholders.

The literature in marketing and business ethics has grown even more voluminous and diversified after 1970s. Most of the models that have emerged are the products of scholars in psychology or related disciplines, including organizational behavior and marketing ${ }^{11}$. However, many researchers have worked on marketing ethics era and developed several theories ${ }^{12}$. Mayo and Marks (1990) ${ }^{13}$ also focused their research on the influences of deontological and teleological evaluations on the ethical judgments of marketing researchers as well as the relationship between ethical judgments and ethical intentions.

Deontological (or rule-based) theories and teleological (or consequential) theories are the two broad categories of normative ethics theory. Deontological theories assume that a set of universal rules define what is right. These rules are "means"-oriented and accepted as guidelines for action. Fundamental to deontological theories is the inherent rightness of the behavior. Teleological theories, on the other hand, address the rightness or wrongness of an action on the basis of its consequences. One formulation of this type of theory is utilitarianism, which emphasizes creating the maximum benefits for the largest number of people, while incurring the least amount of damages ${ }^{14}$.

Another study focused on the influences of organizational ethical culture, and locus of control on deontological norms, and ethical perceptions ${ }^{15}$. Singhapakdi and Vitell (1996) ${ }^{16}$ in their research, also examine the impact of the intensity of a moral issue on perceptions of an ethical problem and intentions. They explored the aspects of moral intensity investigated are the extent of consequences, social consensus, the probability of effect, temporal immediacy, proximity, and the concentration of effect.

In the long run, ethics and social responsibility issues should have positive impacts on the success of an organization. A responsible and ethical business practice

11 H. Tseng et.al. "Modern Business Ethics Research: Concepts, Theories, and Relationships” Journal of Business Ethics, 91(4), 2009, pp.587-597.

12 S.D. Hunt and S.A. Vitell, "General Theory of Marketing Ethics" Journal of Macro Marketing, 6(1), 1986, pp. 5-16; A.J. Dubinsky and B. Loken, "Analyzing Ethical Decision Making in Marketing", Journal of Business Research, 19(2), 1989, pp. 83- 107; O.C. Ferrell et.al. "A Synthesis of Ethical Decision Models for Marketing”. Journal of Micromarketing, Fall, 1989, pp. 55-64.

13 Michael A. Mayo et.al. "An Empirical Investigation of a General Theory of Marketing Ethics", Journal of the Academy of Marketing Science, 18, 1990, pp. 163-171.

14 James Y.L. Thong and Chee-Sing Yap, "Testing an Ethical Decision-Making Theory: The Case of Softlifting”, Journal of Management Information Systems, 15(1), 1998, pp. 213-237.

15 Anusom Singhapakdi and Scott J. Vitell, "Marketing Ethics: Factors Influencing Perceptions of Ethical Problems and Alternatives.” Journal of Macro Marketing 10, 1990, pp. 4-18.

16 Singhapakdi and Vitell, ibid. pp.4-18. 
concludes in better customer and employee relations. This is why ethical judgments are made by consumers as well, and these judgments are likely to influence the consumers' acceptance or rejection of a company's products ${ }^{17}$.

Marketing ethics and social responsibility issues are relating to the concepts of business ethics, community investment, environment, governances, human rights, market place and workplace. Corporate social responsibility is related to the social contract between business and the society ${ }^{18}$. Steiner (1972) elucidated the concept of social contract as: "At any one time in any society there is a set of generally accepted relationships, obligations and duties between the major institutions and the people." The concept of corporate social responsibility (CSR) is viewed as a comprehensive set of policies, practices and programs that are integrated into business operations, supply chains, and decision-making processes throughout the company and includes responsibility for current and past actions as well as future impacts. CSR goes beyond charity and requires that a responsible company take into full account of the impact on all stakeholders and on the environment when making decisions ${ }^{19}$.

Murray and Vogel (1997) ${ }^{20}$ found that CSR actions significantly predict purchase intentions. Consumers' purchase intentions were related to whether the company's ethics record exceeded their expectation. It is revealed that consumers expressed willingness to pay more for ethically made products ${ }^{21}$. A model of consumer influence (in terms of special interest groups and boycotts) on CSR is proposed by Smith (2001). Researchers also coined the term of corporate societal marketing to describe a range of ten activities that have economic and noneconomic objectives and influence social welfare. They show that questionable or unfair business practices may create serious penalties for the companies. Unethical firm behavior may damage firm reputation and decrease consumer trust $\mathrm{t}^{22}$.

17 E.C. Alexander, "Consumer Reactions to Unethical Service Recovery", Journal of Business Ethics, 36, 2002, pp. 223-237; Anusorn Singhapakdi, "Perceived Importance of Ethics and Ethical Decisions in Marketing", Journal of Business Research, 45(1), 1999, pp. 89-99.

18 Donald P. Robin, and R. Eric Reidenbach, "Social Responsibility, Ethics, and Marketing Strategy: Closing the Gaps between Concept and Application", Journal of Marketing, 51, 1987, pp.44-58.

19 M. Mohamed Labbai, "Social Responsibility and Ethics in Marketing”, International Marketing Conference on Marketing \& Society, 8-10 April, IIMK. 2007.

20 K.B. Murray and C.M. Vogel, "Using a Hierarchy-of-Effects Approach to Gauge the Effectiveness of Corporate Social Responsibility to Generate Goodwill toward the Firm: Financial Versus Nonfinancial Impacts” Journal of Business Research, 38(2), 1997, pp.141-159.

21 P. Auger et.al. "What Will Consumers Pay for Social Product Features?” Journal of Business Ethics, 42(3), 2003, pp. 281-304.

22 Volkan Özbek et. al. "The Impact of Unfair Business Practices on Bank Customers: An Experimental Study”, Ege Academic Review, 12 (1), 2012, pp. 23-30. 


\subsection{Ethical Issues in Marketing}

Within the academic history of marketing, one of the first articles that appeared in the Journal of Marketing was an article by Charles F. Phillips (1939) entitled, "Some Theoretical Considerations Regarding Fair Trade Laws." Most academic publishing in the 1950s focused on issues such as fair trade, antitrust, advertising and pricing ${ }^{23}$. Marketing ethics examines systematically marketing and marketing morality, related to $4 \mathrm{P}$-issues such as unsafe products, deceptive pricing, deceptive advertising or bribery, discrimination in distribution. According to some researchers, the fairness on trade practices construct which are also termed as the micro issues of consumerism consider various exploitative business practices among which the mostly discussed issues are misleading advertising, unfair pricing, deceptive packaging, caring about consumers and environmental issues, product adulteration, black marketing, misbranding practice etc. Some of these factors (misleading advertising, unfair pricing, deceptive packaging, caring about consumers and environmental issues) are used as the core elements for this research to figure out the possible influence on consumers' ethical decisions ${ }^{24}$.

Over the past few years it has been observed that producers are increasingly employing several packaging practices in order to mislead consumers. First, packaging sizes and the relation between packaging size and its content and similar strategies (e.g. adding gifts) are employed in order to lead the consumer into thinking that there is greater quantity of the product. Second, the design of the packaging implies wrongful or misleading information. Third, producers imitate another's packaging in order to imply a certain geographic provenance or quality of the product. Finally, the price may be wrongfully indicated or absent from the packaging 25 . There is a slight degree of skepticism among consumers about quality of products in the market, there is obvious mistrust of the communications manufacturers use to attract buyers to those products $^{26}$. It is possible for the majority of consumers to consider that manufacturers' procedures for handling complaints and settling complaints are not satisfactory.

Hence, marketing scholars and practitioners have long been interested in consumers' perceptions of, and their reactions to different marketing practices. In particular, ethical considerations in advertising are a long standing issue. Advertising is the most visible and the most criticized component of marketing communications. Indeed, some questionable (i.e. ads to children, alcohol and tobacco ads, negative political ads) and deceptive/misleading advertising practices are the very reason for putting

23 O. C. Ferrell, "Nature and Scope of Marketing Ethics", W. Wilkie, G. T. Gundlach and L. Block (eds.), Explorations of Marketing in Society (Thomson-Southwestern, Ohio), 2007, pp. 858-875.

24 M. Ali Quazi, "Managerial Views of Consumerism: A Two Country Comparison”, European Journal of Marketing, 36, (1/2), 2002, pp. 36-50; Sherlaker, ibid. 1999.

25 IMCO, "Internal Market and Consumer Protection: Misleading Packaging Practices", Directorate-General for Internal Policies, European Parliament: Policy Department A: Scientific and Economic Policy, 2012. 
the advertising under fire. As a form of persuasive communication, advertising can easily be used to mislead the target audience ${ }^{27}$. So, deceptive or misleading advertising should be legally defined as: the standard that has generally relied on what a reasonable consumer would take away from an advertisement under the circumstances ${ }^{28}$.

Attas (1999) argued that an advertisement will be deemed misleading or deceptive only if it is reasonable to expect that persons exposed to it, or those targeted by it, would come to hold false beliefs as a result of exposure to it. It might be thought that the consumer mislead by an advertisement will be tempted to buy the advertised product and in that way either getting less than he thought he would or paying more than he should. Furthermore, the consumer's skepticism about the fairness of advertising can cause them to ignore ethical consideration for buying products ${ }^{29}$.

Unfair pricing is also a burning consumerist issue since pricing is the most sensitive issue to the consumers. Ethically, price should be equal or proportional to benefit which is taken by the consumers. French et.al. (1982) and Lisa, (2004) found that majority of the respondents believe that price charged by the companies is excessive and unfair ${ }^{30}$. Uusitalo and Oksanen (2004) $)^{31}$ argued that fairness with pricing is an important consideration among the consumers in involving in the pro-ethical or pro-consumerist purchasing.

Additional ethical issues connected to pricing consist of non-price price increases, misleading price reduction, price advertisements which can be misleading or considered as deceitful and their limits are not explained well, the practices of price fixing that affect the structure of competition, predatory pricing which aims to have monopolistic position, discriminatory pricing, pricing applications of products according to the products' unit or quantity basis and practicing of misleading pricing methods $^{32}$.

Ellen, Wiener and Cobb-Walgren (1991) and Shrum, McCarty and Lowrey (1995) argued that consumers' skepticism regarding the environmental consumerism practice discourage them to be involved in ethical and pro-environmental purchasing $^{33}$. These practices also known as green marketing and green marketing refers to the development and distribution of ecologically-safe products. Mingquan (2003) ${ }^{34}$

27 Özbek et. al. ibid. pp.23-30.

28 S. Koslow, "Can the Truth Hurt? How Honest and Persuasive Advertising Can Unintentionally Lead to Increased Consumer Skepticism", Journal of Consumer Affairs, 34(2), 2000, pp. 14.

29 Ismail and Panni, ibid. pp. 43-64.

30 Ismail and Panni, ibid. pp. 43-64.

31 Quit Uusitalo and Retta Oksanen, "Ethical consumerism - a view from Finland”, International Journal of Consumer Studies, 28(3), 2004, pp. 214.

32 Chonko, ibid. 1995.

33 Ismail and Panni, ibid. pp. 43-64.

34 Z., Green Mingquan, Food Market Promises Bright Future, Market Trend, Available http://www.tdctrade.com/report/mkt/mkt_031002.htm. (13 October 2003). 
revealed that the organizations have growing concerns towards the environmental consumerism. Charter (1992); Moisander (2001) ${ }^{35}$ argued that the consumer pro-environmental purchasing behavior is positively influenced by the availability of the ethical and social responsible firms that offer environmental friendly or sound products.

Customer care is another very important issue for any business in satisfying their customers because proper customer care can create an image to the customers as the ethical and social responsible firm. French et.al. (1982) defined customer care as the companies' engagement in complaint handling and after sales service to the customers $^{36}$. Companies should try to provide a value added service through; polite and courteous service, offering confidentiality and an open door policy, proactive problem solving and guidance and handling request in timely and rational manner.

Before proceeding to ethical decision-making process, it must be clearly explored the difference between ethical issues and ethical dilemmas. An ethical issue is a problem, situation, or opportunity that requires an individual, group or organization to choose among several actions that must be evaluated as right or wrong. On the contrary, an ethical dilemma is a problem, situation or opportunity that requires an individual, group or organization to choose among several wrong or unethical actions ${ }^{37}$. For marketers and other professionals, ethical dilemmas arise when responsibilities and loyalties conflict and a decision about the appropriate or ethical course of action must be made. Often a choice is required among alternative actions that meet the obligations or competing interests. In this respect, an ethical decision-making process can be helpful to guide the decision makers to address significant issues that should be considered before taking action ${ }^{38}$.

\subsection{Ethical Decision Making Process}

To effectively enhance ethical and socially responsible practices in marketing, it is important for managers and policymakers to have a better understanding of the marketers' ethical/socially responsible decision processes. Ethical decision-making refers to the process of evaluating and choosing among alternatives in a manner consistent with the ethical principles. In making ethical decisions, it is necessary to perceive and eliminate unethical options and select the best ethical alternative ${ }^{39}$.

The ethical decision-making process includes several steps that must be pursuing to determine the right course of action or resolve an ethical dilemma. The first

35 M. Charter, Green Marketing: The introduction; marketing practices, Fagbokforlaget, Norway, 1992; J. Moisander, Representation of Green Consumerism: A Constructionist Critique, Helsinki School of Economics, Helsinki, A: 185, 2001.

36 Ismail and Panni, ibid. pp. 43-64.

37 J. Fraedrich, L. Ferrell and O.C. Ferrell, Ethical Decision Making in Business-A Managerial Approach, Cengage Learning, Ninth Edition, South Western, 2013.

38 R. K. Fitzpatrick and C. Gauthier, "Toward a Professional Responsibility Theory of Public Relations Ethics”, Journal of Mass Media Ethics, 16(2\&3), 2001, pp.193-212.

39 Singhapakdi, ibid. pp.89-99. 
step is to determine the facts of the situation that the decision maker should make an honest effort to understand the problem. Identifying the ethical issues involved is the next step in making responsible decisions. It's an ability to recognize a decision as an ethical one. The third step is necessary to identify relevant factors like stakeholders or laws or professional codes ${ }^{40}$ and consider the situation from their point of view who will affected by a decision, policy or operation of a firm. Once the facts have examined, it is needed to consider the available alternatives which is also called the moral imagination. It is important not only to consider the obvious options with regard to particular dilemma, but also much more subtle ones. The next step in decision making process is to compare and weigh the alternatives which create a mental spreadsheet that evaluates the impact of each alternative devised on each stakeholder. Once the variables have explored, it is time to make a rational and reasonable decision or select a course of action among the supported ethical alternatives. The final step of the process is to evaluate the implications of the selected course of action to monitor and learn from the outcomes and to modify the actions according to face with the similar challenges in the future ${ }^{41}$.

It is assumed that the ethical decision making process is affected by a variety of individual, situational, and contextual factors such as personal experiences, opportunity, the organizational environment and the cultural environment. Sometimes it is difficult to distinguish what is morally acceptable or unacceptable, since the judgment of ethical behavior is in the eye of the beholder ${ }^{42}$. It is an inevitable reality for many companies and managers that there is a conflict between difficulties of economic environment and making ethical decisions in today's competitive markets It would be easier to make ethical decisions if a company aims a satisfactory profit range instead of pursuing a profit maximization approach ${ }^{43}$.

Hunt and Vitell (1986) ${ }^{44}$ use their moral theories as core components of their general theory of marketing ethics to explain decision making in situations having ethical content. According to them, ethical decision making is a function of ethical judgment. Researchers investigate some of the factors of ethical decision-making, such as induced values, social knowledge and ethical attitude. The influence of specific situational factors is examined on important components of the marketers' ethical decision-making processes, depicted in marketing and business ethics theories. Researchers also provide a conceptual framework as to how culture influences one's perceptions and ethical decision-making in business ${ }^{45}$.

40 M. Davis, Ethics and the University, New York: Routledge, 1999, pp.166-167.

41 L. P. Hartman and J. Desjardins, Business Ethics: Decision-Making for Personal Integrity and Social Responsibility, McGraw-Hill Publications, New York, 2008, pp.37-42.

42 Özbek et. al., ibid. pp: 23-30.

43 Lawrence B. Chonko, Ethical Decision Making in Marketing, Thousand Oaks: Sage Publications, 1995.

44 Hunt and Vitell, ibid. pp.55-64.

45 R. Reidenbach and D. Robin, "Toward the Development of a Multidimensional Scale for Improving Evaluations of Business Ethics", Journal of Business Ethics, 9(8), 1990, pp. 
Assael (2004) and Aaker and Keller (1990) have indicated the customer purchasing behavior as an important side of the consumer behavioral perspective. Customer purchasing behavior is one of the significant behavioral aspect of consumer behavior. All purchase behavior is in some sense ethical, involving moral judgment. It is necessary to focus on the consumer behavioral perspective in the ethical perspective in terms of the purchasing behavior ${ }^{46}$.

Consumers are concerned regarding the ethical purchasing but the other purchase criteria such as price, value, quality and brand are often important choice criteria than ethics. Ethical purchase behavior, concept defined as "an expression of the individual's moral judgment in his or her purchase behavior ${ }^{47}$ Smith (1990) conducted case research of consumer boycotts, a clearly identifiable form of ethical purchase behavior. He showed how consumers, in conjunction with pressure groups, can use their purchasing power to influence corporate policies and practices. These ethical consumers are "concerned with the effects that a purchasing choice has, not only on themselves, but also on the external world around them ${ }^{48}$.

\section{Research Model and Hypothesis}

Based on the theoretical description and empirical studies, this study asked the following hypotheses: behavior.

$\mathrm{H}_{1}$ : Misleading advertising has a significant impact on consumer purchasing havior.

$\mathrm{H}_{2}$ : Deceptive packaging has a significant impact on consumer purchasing be-

$\mathrm{H}_{3}$ : There is a significant influence of environment care on consumer purchasing behavior. behavior.

$\mathrm{H}_{4}$ : There is a significant influence of customer care on consumer purchasing

This study intends to link perception of customers on companies' ethical practices to purchasing behavior. We propose that ethical issues serve as the antecedents

639-653; A. Singhapakdi et.al., "Moral Intensity and Ethical of Marketing Professionals Decision-Making”, Journal of Business Research 36, 1996, pp. 245-255; S. J. Vitell et.al., "Marketing Norms: The Influences of Personal Moral Philosophies and Organizational Ethical Culture", Journal of the Academy of Marketing Science, (21), 1993, pp. 331-337.

46 N. Al-Mazrooei et.al. "Purchasing Behavior of Consumers for Seafood Products", Agricultural and Marine Science, 8(1), 2003, pp. 1-10.

47 E. Boulstridge and M. Carrigan, "Do Consumers Really Care About Corporate Responsibility? Highlighting the Attitude Behavior Gap", Journal of Communication Management, 4, 2000, pp. 355-368; N. C. Smith, Morality and the Market: Consumer Pressure for Corporate Accountability (London: Routledge), 1990.

48 Iain A. Davies et.al. "Do Consumers Care About Ethical Luxury?" Journal of Business Ethics, 106, 2012, pp. 37-51. 
to purchasing behavior. All hypotheses are offered to have a positive effect. The conceptual model is presented in Figure 1 given below.

\section{Figure 1. Research Model}

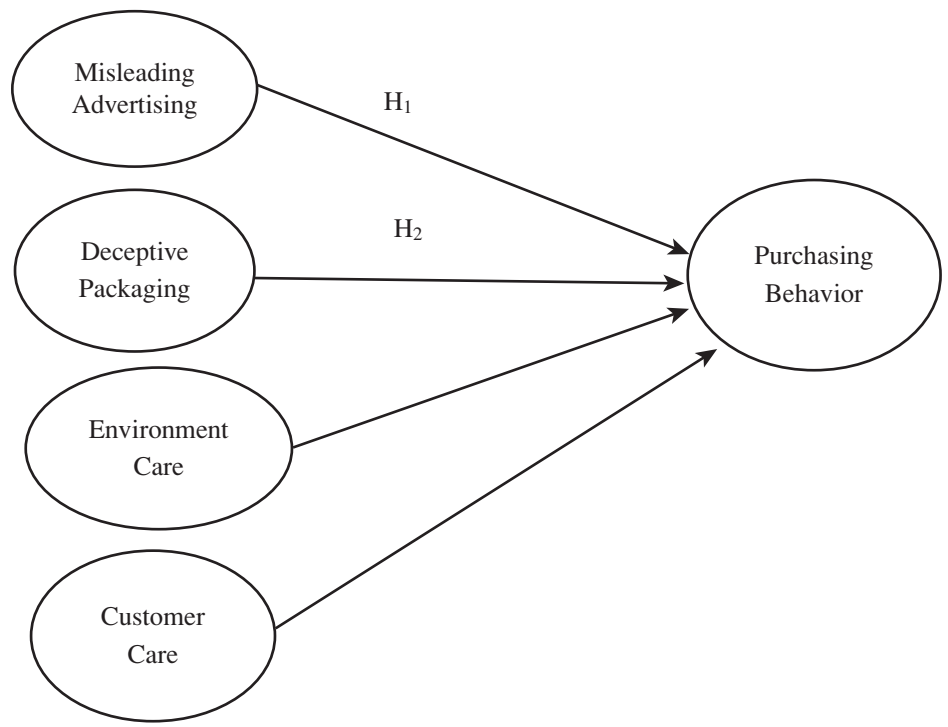

\section{Research Methodology}

4.1. Sample Selection and Data Collection Procedure: This study aims to reveal the university students' perception on ethical issues of companies. The study requires respondents to have information about ethical marketing issues or ethical marketing practices of companies, such as practices on advertising, packaging and so on. Having the students being informed about these issues, they were asked for the survey. A sample of 400 surveys was gathered via judgmental sampling technique. Respondents were selected among the students studying at Ahi Evran University in Kurşehir. This study used the information about companies' marketing practices as the composition and selection of the sample. In order to provide that all respondents have information about marketing, we selected the sample from the students on the last semester in their education. Overall, 350 out of 400 respondents completed the questionnaires following to excluding missing data. The effective response rate was approximately $\% 80$.

\subsection{Limitations of the Study}

This study is limited with university students. Respondents are selected among the students having knowledge about business ethics and the issues that can be considered as ethical/unethical practices of businesses. So it gives no information about whole end consumers' interest on ethical issues of businesses. 
The second limitation of the study is the disregarding of demographic variables. Demographic variables, such as gender, age, occupation, income level, and their possible influences on ethical decision making are ignored. The study is also limited with only four dimensions related with businesses' ethical practices.

4.3. Questionnaire Design: The variables of this study include "misleading advertising", "deceptive packaging", "environment care", "customer care" and "consumer purchasing behavior". Questionnaire items have been developed based on the literature review. There are total 19 questions with Likert-type scale. All constructs in the model were measured with multiple-item scale. Each of the variables was measured by five-point-Likert-type scale, ranging from 1 (strongly unimportant) to 5 (strongly important). They were given respectively 1 point, 2 points, 3 points, 4 points and 5 points. The higher the score, the more important the item (about the ethical practices of companies) is for customer. Dimensions used in the study and the items used to measure these dimensions are presented in Table 1.

Table 1. Dimensions/Scale Items

\begin{tabular}{|l|l|}
\hline Items & Dimensions \\
\hline $\begin{array}{l}\text { True picture of advertisement } \\
\text { Correct information about product characteristics in advertisement } \\
\text { True claims of advertisement for products and services } \\
\text { Avoiding to use exaggerated claims and pictures } \\
\text { Real presence of the products in advertisements }\end{array}$ & Misleading Advertisement \\
\hline $\begin{array}{l}\text { Proper information on package or label } \\
\text { Expire date on label or package } \\
\text { Fair price on label or package }\end{array}$ & Deceptive Packaging \\
\hline $\begin{array}{l}\text { Considering the effects of products on environment } \\
\text { Offering products in recyclable package } \\
\text { Offering products which cause less pollution } \\
\text { Offering environmentally certified products }\end{array}$ & Environment Care \\
\hline $\begin{array}{l}\text { Caring the customers' complaints } \\
\text { Company's effort for settling grievances } \\
\text { Caring customers after purchasing as well. } \\
\text { Working especially for customer satisfaction }\end{array}$ & \\
\hline $\begin{array}{l}\text { Buying products from socially responsible companies } \\
\text { Considering ethical issues while purchasing } \\
\text { Switching products for ethical reason }\end{array}$ & Customer Care \\
\hline
\end{tabular}

A total of the five items were given on the dimensions of "misleading advertising", using Ismail and Panni (2008) $)^{49}$ as a reference. "Deceptive packaging" dimension was measured via three items and adopted from the mentioned study. Scale on the dimensions of companies "environment care and "customer care" were also based on this study. A total of four items were given on each of these dimensions. As four purchasing behavior dimension scales, some ideas came from Iftekhar et al., (2013);

49 Ismail and Panni, ibid. pp. 43-64. 
Uusitalo and Oksanen, (2004); Day et al., (1991) ${ }^{50}$ and three items were given to measure. It consisted of three dimensions, including "buying products from socially responsible companies", "considering ethical issues when purchasing" and "switching products for ethical reasons" to reflect their interest in ethical issues in their decision making.

Questionnaire (survey) consisted of five sections, four of which are related with consumers' perception on ethical issues and their purchasing behavior. Last section consisted of questions including respondents' characteristics. The questionnaire consisted of respondents' gender, age, marital status, education level and number of people within the household and household average income.

4.4. Methods (Data Processing and Analysis): This study analyzed the demographic background of respondents, descriptive studies and exploratory factor analysis with using SPSS 20.0 statistical software. Besides, regression analysis was used to test hypothesis via the same analytic software. The Cronbach's Alpha test was used for the reliability analysis, so as to see the internal consistency.

\section{Data Analysis Results}

5.1. Sample Characteristics: Of the respondents, 70 percent are male and 30 percent are female. 90 percent are between 18 and 25 years old, for the sample selection has been based on university students. 92 percent of the respondents are unmarried. The average number of persons within the households is 3 . That is, more than 50 percent of the respondents live with more than 3 people in their house. 44 percent of the respondents state their household average income between the level of 501 and 1500, whereas only 10 percent state income level above 3000 .

5.2. Descriptive Analysis: The below table demonstrates the mean scores of each statement of customers' perception on misleading advertising, deceptive packaging and so on. The mean score on ethical issues of companies and purchasing behavior in Table 2 shows that almost all respondents give importance to the items. Especially, almost all items standing for customer care have high mean scores. The item "proper information on package or label" has the highest mean i.e. 4, 83, while the item "avoiding using exaggerated claims and pictures" has the lowest. That is, the respondents are not very much interested in "exaggerated claims and pictures in advertisements". "Proper information on package" is considered to be the most important item.

50 H. Iftekhar et.al., "Detrimental Effects of Marketing Practices on Consumers' Buying Behaviors", Business Management Dynamics, 2(10), 2013, pp. 01-05; Uusitalo and Oksanen, ibid., pp. 214; Day, D., Gan, B., Gendall, P. and Esslemant, D., "Predicting Purchase Behavior", Marketing Bulletin, 2, 1991, pp.18-30. 
Table 2. Results of Descriptive Statistics

\begin{tabular}{|c|c|c|}
\hline Items & Mean & $\begin{array}{r}\text { Std. } \\
\text { Deviation }\end{array}$ \\
\hline \multicolumn{3}{|l|}{ Misleading Advertisement } \\
\hline True picture of advertisement & 4.37 & .994 \\
\hline Correct information about product characteristics in advertisement & 4.68 & .827 \\
\hline True claims of advertisement for products and services & 4.58 & .895 \\
\hline Avoiding to use exaggerated claims and pictures & 3.96 & 1.25 \\
\hline Real presence of the products in advertisements & 4.61 & .825 \\
\hline \multicolumn{3}{|l|}{ Deceptive Packaging } \\
\hline Proper information on package or label & 4.83 & .628 \\
\hline Expire date on label or package & 4.64 & .828 \\
\hline Fair price on label or package & 4.21 & 1.28 \\
\hline \multicolumn{3}{|l|}{ Environment Care } \\
\hline Considering the effects of products on environment & 4.51 & .851 \\
\hline Offering products in recyclable package & 4.48 & .861 \\
\hline Offering products which cause less pollution & 4.55 & .831 \\
\hline Offering environmentally certified products & 4.62 & .819 \\
\hline \multicolumn{3}{|l|}{ Customer Care } \\
\hline Caring the customers' complaints & 4.71 & .756 \\
\hline Company's effort for settling grievances & 4.68 & .752 \\
\hline Caring customers after purchasing as well. & 4.58 & .932 \\
\hline Working especially for customer satisfaction & 4.53 & .901 \\
\hline \multicolumn{3}{|l|}{ Purchasing Behavior } \\
\hline Buying products from socially responsible companies & 4.19 & 1.004 \\
\hline Considering ethical issues while purchasing & 4.30 & .928 \\
\hline Switching products for ethical reason & 4.18 & 1.50 \\
\hline
\end{tabular}

It can be inferred from the mean scores that respondents highly take care of ethical issues, particularly deceptive packaging and customer care. However, they moderately give importance to the items representing the ethical decision making to buy. Therefore, it can be said that the customers consider many ethical issues to be important. This result is supported by the prior studies done by Iftekhar et al., (2013); Uusitalo and Oksanen, (2004). ${ }^{51}$ The results also show that the consumers also consider about ethical decision making, because of mean score level ranging from 4.30 to 4.18 , which can be considered as moderately important. These figures resemble with the results studied by Uusitalo and Oksanen $(2004)^{52}$. These studies indicated that consumers give more importance to companies' ethical practices rather than their purchasing behavior shaped by ethical issues.

5.3. Factor Analysis: Explanatory factor analysis is firstly used to understand the relationships of number of items and indicate if they can be reduced to smaller set of factors. This factor analysis yields 5 factors (factor loadings of whom are between).

51 Iftekhar, et.al, ibid. pp.01-05; Uusitalo and Oksanen, ibid. pp.214.

52 Uusitalo and Oksanen, ibid. pp.214. 
All factor loadings are between 0.435 and 0.792 . When the item that has the lowest value was excluded, internal reliability of the construct increased. Hence, the item of "avoiding to use exaggerated claims and pictures", having the lowest factor loading was excluded from the study. Factor loadings for all other items are above $\% 50$, higher than the minimum acceptable level of $40 \%{ }^{53}$. The results are shown in Table 3.

Table 3. Results of Factor Analysis

\begin{tabular}{|c|c|c|c|}
\hline Items & $\begin{array}{l}\text { Factor } \\
\text { Loading }\end{array}$ & $\begin{array}{l}\text { Cronbach's } \\
\text { Alpha } \\
\text { Internal } \\
\text { Reliability }\end{array}$ & $\begin{array}{l}\text { Percentage } \\
\text { of Variance } \\
\text { Explained }\end{array}$ \\
\hline Misleading Advertisement & & & \\
\hline True picture of advertisement & .622 & \multirow{5}{*}{.821} & \multirow{5}{*}{40.188} \\
\hline $\begin{array}{l}\text { Correct information about product } \\
\text { characteristics in advertisement }\end{array}$ & .768 & & \\
\hline $\begin{array}{l}\text { True claims of advertisement for products and } \\
\text { services }\end{array}$ & .720 & & \\
\hline Avoiding to use exaggerated claims and pictures & .435 & & \\
\hline Real presence of the products in advertisements & .581 & & \\
\hline \multicolumn{4}{|l|}{ Deceptive Packaging } \\
\hline Proper information on package or label & .763 & \multirow{3}{*}{.854} & \multirow{3}{*}{9.902} \\
\hline Expire date on label or package & .756 & & \\
\hline Fair price on label or package & .741 & & \\
\hline \multicolumn{4}{|l|}{ Environment Care } \\
\hline $\begin{array}{l}\text { Considering the effects of products on } \\
\text { environment }\end{array}$ & .705 & \multirow{4}{*}{.862} & \multirow{4}{*}{8.058} \\
\hline Offering products in recyclable package & .740 & & \\
\hline Offering products which cause less pollution & .655 & & \\
\hline Offering environmentally certified products & .695 & & \\
\hline \multicolumn{4}{|l|}{ Customer Care } \\
\hline Caring the customers' complaints & .612 & \multirow{4}{*}{.872} & \multirow{4}{*}{5.622} \\
\hline Company's effort for settling grievances & .755 & & \\
\hline Caring customers after purchasing as well. & .782 & & \\
\hline Working especially for customer satisfaction & .792 & & \\
\hline \multicolumn{4}{|l|}{ Purchasing Behavior } \\
\hline $\begin{array}{l}\text { Buying products from socially responsible } \\
\text { companies }\end{array}$ & .572 & \multirow{3}{*}{.712} & \multirow{3}{*}{5.380} \\
\hline Considering ethical issues while purchasing & .748 & & \\
\hline Switching products for ethical reason & .697 & & \\
\hline \multicolumn{4}{|l|}{$\begin{array}{l}\text { Total Variance Explained }(\%)=69.15 \\
\text { KMO Measure of Sampling Adequacy }=.893 \\
\text { Bartlett's Test of Sphericity df }=171 ; \text { Sig. }(p=.000)\end{array}$} \\
\hline
\end{tabular}

Extraction: Principal Component Analysis; Rotation: Varimax with Kaiser Normalization.

53 J.F. Hair, Multivariate Data Analysis, Prentice-Hall, Inc., International Fifth Edition, New Jersey, USA. 1998. 
Before testing hypothesis, reliability and validity tests are necessary to standardize the measurement scales and to show if they truly measure what they are supposed to measure. The reliability analysis was conducted by Cronbach's alpha coefficients. Cronbach's alpha for all dimensions are required to be above the minimum acceptable score of $70 \%{ }^{54}$. The value of Cronbach's alpha for all constructs is higher than $70 \%$, ranging from $71 \%$ to $87 \%$ in our study. This factor analysis presents five factors that account for $69 \%$ of the total variance, above the minimum acceptable value of $60 \%{ }^{55}$. The scale of all constructs shows good measurement properties. The result of all measures of scale can be considered to be internally consistent. Based on the results factor analysis is suitable as well, because of the significant value of Kaiser Meyer-Olkin $(\mathrm{KMO}=0.893$; between 0.5 and 1$)$ and the statistical test for Bartlett's test of Sphericity $(\mathrm{p}=0.000 ; \mathrm{p}<0.05)^{56}$.

\section{Hypothesis Testing and Implications}

This study examined the effects of companies' ethical issues on consumer purchasing behavior. The results are shown in Table 4. The result of the multiple regression analysis for hypothesis 1 reveals a significant effect of misleading advertising on purchasing behavior $(\mathrm{p}<0.01)$. That is, the more ethically the company uses its advertising practices, the more likely the consumers purchase from this company. As a result, the first hypothesis $\left(\mathrm{H}_{1}\right)$ is supported.

Table 4. Results of Multiple Regression Analysis

\begin{tabular}{|c|c|c|c|}
\hline Independent Variables & $\begin{array}{c}\text { Standardized } \\
\text { Beta Coefficients }\end{array}$ & t-value & Sig. \\
\hline Misleading Advertising & .280 & 9.341 & $.000^{* * *}$ \\
\hline Deceptive Packaging & .727 & 24.243 & $.000^{* * * *}$ \\
\hline Environment Care & .302 & 10.079 & $.000 * * *$ \\
\hline Customer Care & .051 & 1.686 & $.093^{*}$ \\
\hline \multicolumn{4}{|c|}{$\begin{array}{l}\text { Notes: Dependent Variable: Purchasing Behavior } \\
\mathrm{R}=0.837 \text {; R Square }=0.701 ; \text { Adjusted R Square: } 0.698 \\
\text { F value of ANOVA }=194,850 ; \mathrm{p} \text { value }=0.000(\mathrm{p}<0.05)\end{array}$} \\
\hline
\end{tabular}

The $\mathrm{p}$ value of deceptive packaging $(\mathrm{p}=0.000)$ is significant at the $0.01 \mathrm{lev}$ el $(p<0.01)$ and beta coefficient is 0.727 . Thus, the study indicates that deceptive packaging has a significant influence on purchasing behavior and $\mathrm{H}_{2}$ is supported. The results also show that deceptive packaging is the most important antecedent of purchasing behavior, because of showing highest importance to the identified model of $t$ value 1.686 and $\beta=0.051$.

54 J.F. Hair, Multivariate Data Analysis. Upper Saddle River, NJ: Prentice Hall, 2006.

55 Hair et.al. Multivariate Data.......ibid. 2006.

56 Hair et. al., Multivariate Data......ibid. 1998. 
The result of the multiple regression analysis for hypothesis 3 also presents significant positive relation. Environment care is positively related to purchasing behavior, as regards the p value of $0.000(\mathrm{p}<0.01)$. Therefore $\mathrm{H}_{3}$ is also supported. Environment care shows higher relative importance to the identified model of $t=10.079$ and $B=0.302$, when compared to misleading advertising and customer care. That means, businesses environmental practices such as producing ecologically safe and environmental friendly products can be a determinant factor on ethical decision making process. Similarly, as Ellen, Wiener and Cobb-Walgren (1991) ${ }^{57}$ indicated, businesses disregarding environment will lead consumers to perceive them as unethical. Thus, consumers are more likely to negatively evaluate these type of businesses, on their ethical decision making process. The variable of customer care is significant the 0.10 level, since the $\mathrm{p}$ value of it is $0.093(\mathrm{p}<0.10)$. It indicates that companies' caring of customers is positively related to purchasing behavior. Yet, it has the lowest effect.

The study reveals that each variable has a positive effect on purchasing behavior. That means when the consumers' interest on ethical issues and their positive perception on ethical practices of business increase, they are more likely to reflect their interest to their purchasing behavior. The values of beta coefficient among the independent variables tested in the hypothesis ranged from the weakest relationship of 0.051 (between customer care and purchasing behavior) to the strongest relationship of 0.727 (between deceptive packaging and purchasing behavior). It can be inferred that deceptive packaging is the most powerful antecedent in affecting purchasing behavior, whereas company's caring of customers is the weakest. The variability in purchasing behavior is explained $70 \%$ by combination four variables, including misleading advertising, deceptive packaging, environment and customer care. The value of adjusted $\mathrm{R}$ square indicates that $70 \%$ of the change in purchasing behavior is explained by combination of four variables, including misleading advertising, deceptive packaging, environment and customer care. Besides, the F value of ANOVA, 194,850 $(\mathrm{p}<0.05)$, shows that independent variables are associated with purchasing behavior.

\section{Conclusion}

In this study through the related literatures review and hypothesis, conclusions pointed out that companies' practices on packaging and advertising influence the consumers purchasing behavior. Besides, consumers' perception on companies' customer and environment have an impact on their purchasing behavior. Thus, each variable influences the purchasing behavior. As Murphy, (2001); Smith, (2001) ${ }^{58}$ indicated that companies' considering ethical issues positively influence consumers' purchase intentions. Likewise Alexander (2002) ${ }^{59}$ offered, consumers are so sensitive as to un-

57 Ismail and Panni, ibid. pp. 43-64.

58 P. E. Murphy, Corporate ethics statements: An update, In Williams, O. F. (Ed). Global Codes of Conduct, Notre Dame, IN: University of Notre Dame Press, 2001, pp. 295-304; N.C. Smith, "Changes in Corporate Practices in Response to Public Interest Advocacy and Actions”. In Bloom, P.N., \& Gundlach, G.T. (Eds). Handbook of Marketing and Society, Thousand Oaks, CA: Sage Publications, 2001, pp. 140-161.

Alexander, ibid. pp.223-237. 
derstand whether the company has ethical responsibility. They are so likely to evaluate the rightfulness and honesty of company's practices. In this study it is inferred from the results of descriptive statistics that consumers consider ethical issues to be important and the results of hypothesis testing reveals that consumers are more likely to reflect this importance to their behaviors.

This study reveals that companies' practices on packaging are the most effective ethical issue on purchasing behavior. Consumers can figure out that companies can mislead them through deceptive packaging and understand the importance of it. Misleading information on package, wrongfully indicated price on package i.e. are seriously considered by consumers. Misleading practices on advertising are also effective on purchasing behavior. As Ismail and Panni (2008) ${ }^{60}$ indicated, if the consumers do not certain about advertisement, it is possible for them to deny the company's product. Because consumers want to believe that they pay not more than the value of the product and misleading advertising is a tool to show the value of the product more than its real value. All these unethical issues discourage consumers to purchase.

Beyond the theoretical contributions, this study also makes practical contributions for companies and for future researches. It is seen that consumers are sensitive to evaluate companies' practices and their evaluations reflect to behavioral outcome. Thus, companies should spend more time about their ethical practices. Companies sometimes cannot recognize the impact of some variables. For instance, environment is the mostly argued issue among these variables in literature, including ecologically safe products, green marketing, pro-environmental purchasing and so on. However, each variable has a certain effect and all have become evaluation criteria for consumers. Programs and strategies should be designed to include possibly many variables. They should recognize consumer behavior, ethically shaped. It is also necessary for companies to create a future orientation.

Companies are also advised to more often declare their ethical practices. They are suggested to make the consumers aware of their ethical issues. They should indicate that ethical issues consist of many practices, not only the environment, which is mostly known, but also packaging, advertising. When compared to companies' packaging, advertising and environmental practices, consumers do not give so much importance to companies' caring of them such as working mainly for their satisfaction, settling for their complaints i.e. on their ethical purchasing decision. It is advisable for the companies to make great effort on packaging or labeling practices, because of its strongest effect on ethical decision making.

Despite this study's contribution to some finding, it has some limitations. Firstly it is limited with university students. That means most characteristics of the sample, which can be important for ethical evaluation such as age, education level, are the same. Moreover, it is true that ethical perceptions and evaluations can change with different cultures. So future researchers can be suggested considering different market segments, shaped by different demographic variables and cultural environment. 
According to so many researchers ethical issues or practices of companies are not enough for the success of companies ${ }^{61}$. Regarding the results of these studies, there are other criterias being evaluated such as price, quality, brand name and so on. So future researches can evaluate both ethical perception of consumers and their perception on brand, quality, price i.e. together. So that it can be indicated which one is relatively more important from the perspective of consumers' perception.

61 Boulstridge and Carrigan, ibid. pp. 355-368; Smith, Morality and the Market.... ibid. 1990. 


\section{References}

AAKER, D.A. and Keller, K.L., "Consumer Evaluations of Brand Extensions”, Journal of Marketing, 54(1), 1990, pp. 27-41.

AHMAD, M., Akhtar, N., Awan, M. H. A. and Murtaza, G., "Ethical Evaluation of Pharmaceutical Marketing in Pakistan”, Acta Bioethica, 17(2), 2011, pp. 215224.

ALEXANDER, E.C., "Consumer Reactions to Unethical Service Recovery”, Journal of Business Ethics, 36, 2002, pp. 223-237.

AL-MAZROOEI, N. and Chomo, G.V. and Omezzine, A., "Purchasing Behavior of Consumers for Seafood Products", Agricultural and Marine Science, 8(1), 2003, pp. 1-10.

ASSAEL, H., Consumer Behavior- A strategic Approach. Houghton Mifflin Company, Berkeley Street, Boston, 2004.

AUGER, P. and Burke, P.F., Devinney, T.M. and Louviere, J.J., "What Will Consumers Pay for Social Product Features?” Journal of Business Ethics, 42(3), 2003, pp. 281-304.

BOULSTRIDGE, E. and Carrigan, M., "Do Consumers Really Care About Corporate Responsibility? Highlighting the Attitude Behavior Gap", Journal of Communication Management, 4, 2000, pp. 355-368.

CHARLES F. P., "Supermarket and Chain-Store Food Prices”, The Journal of Business, 12, 1939, pp.323.

CHARTER, M., Green Marketing: The introduction; marketing practices, Fagbokforlaget, Norway, 1992.

CHONKO, L. B., Ethical Decision Making in Marketing, Thousand Oaks: Sage Publications, 1995.

COOPER-MARTIN, E. and Holbrook, M. B., "Ethical Consumption Experiences and Ethical Space” Advances in Consumer Research, 20, 1993, pp. 113-118.

DAVIES, I. A., Lee, Z. and Ahonkhai, I., "Do Consumers Care About Ethical Luxury?” Journal of Business Ethics, 106, 2012, pp. 37-51.

DAVIS, M., Ethics and the University, New York: Routledge, 1999, pp. 166-167.

DAY, D., Gan, B., Gendall, P. and Esslemant, D., "Predicting Purchase Behavior", Marketing Bulletin, 2, 1991, pp.18-30.

DRUMWRIGHT, M. E., Ethical Issues in Advertising and Sales Promotion, Boston: Irwin, 1993, pp. 607-625.

DUBINSKY, A.J. and Loken, B., "Analyzing Ethical Decision Making in Marketing”, Journal of Business Research, 19(2), 1989, pp. 83- 107.

ELLEN, P.S., Wiener, J.L. and Cobb- Walgren, C., "The Role of Perceived Consumer Effectiveness in Motivating Environmentally Conscious Behaviors", Journal of Public Policy and Marketing, 10(2), 1991, pp.102-117. 
FERRELL, O. C., "Nature and Scope of Marketing Ethics", W. Wilkie, G. T. Gundlach and L. Block (eds.), Explorations of Marketing in Society (Thomson-Southwestern, Ohio), 2007, pp. 858-875.

FERRELL, O.C. and Ferrell, L., "Ethics and Marketing Education.” Marketing Education Review, 14 (3), 2005, pp.71-79.

FERRELL, O.C. and Gresham, L.G., “A Contingency Framework for Understanding Ethical Decision Making in Marketing.” Journal of Marketing, 49: 3, 1985.

FERRELL, O.C., “A Framework for Understanding Organizational Ethics: New Challenges for Business Schools and Corporate Leaders". R.A. Peterson and O.C. Ferrell, (eds.) Armonk, New York: M.E. Sharpe, 2005, pp. 3-17.

FERRELL, O.C., Gresham, L. and Fraedrich, J., "A Synthesis of Ethical Decision Models for Marketing”. Journal of Micromarketing, Fall, 1989, pp. 55-64.

FITZPATRICK, R. K. and Gauthier, C., “Toward a Professional Responsibility Theory of Public Relations Ethics", Journal of Mass Media Ethics, 16(2\&3), 2001, pp. 193-212.

FRAEDRICH, J., Ferrell, L and Ferrell, O.C., Ethical Decision Making in Business-A Managerial Approach, Cengage Learning, Ninth Edition, South Western, 2013, pp. 102-107.

HAIR, J.F., Anderson, R.E., Tatham, R.L. and Black, W.C., Multivariate Data Analysis, Prentice-Hall, Inc., International Fifth Edition, New Jersey, USA., 1998.

HAIR, J.F., Black, W.C., Babin, B., Anderson, R.E. and Tatham, R.L., Multivariate Data Analysis. Upper Saddle River, NJ: Prentice Hall, 2006.

HARRISON, R., Newholm, T., and Shaw, D., The Ethical Consumer, London: Sage Publications, 2005.

HARTMAN, L. P. and Desjardins, J., Business Ethics: Decision-Making for Personal Integrity and Social Responsibility, McGraw-Hill Publications, New York, 2008, pp. 37-42.

HUNT, S.D. and S.A. Vitell, "General Theory of Marketing Ethics” Journal of Macro Marketing, 6(1), 1986, pp. 5-16.

IFTEKHAR, H., Ayub, A., Razzaq, A. and Aslam, M.S., "Detrimental Effects of Marketing Practices on Consumers' Buying Behaviors”, Business Management Dynamics, 2(10), 2013, pp. 01-05.

IMCO, "Internal Market and Consumer Protection: Misleading Packaging Practices", Directorate-General for Internal Policies, European Parliament: Policy Department A: Scientific and Economic Policy, 2012.

ISMAIL, H., and Panni, M. F. A. K., "Consumers Perceptions on the Consumerism Issues and Their Influence on Their Purchasing Behavior: A View from Malaysian Food Industry", Journal of Legal, Ethical and Regulatory Issues, 11(1), 2008, pp. 43-64. 
KAYNAK, E., "Some Thoughts on Consumerism in Developed and Less Developed Countries”, International Marketing Review, 2, 1985, pp. 15-31.

KOSLOW, S., "Can the Truth Hurt? How Honest and Persuasive Advertising Can Unintentionally Lead to Increased Consumer Skepticism”, Journal of Consumer Affairs, 34(2), 2000, pp. 14.

KOTLER, P., Marketing Management: Analysis, Planning, Implementation and Control, 9th ed., Prentice Hall, Inc., Englewood Cliffs, NJ. 1997.

LABBAI, M. Mohamed, "Social Responsibility and Ethics in Marketing”, International Marketing Conference on Marketing \& Society, 8-10 April, IIMK. 2007.

LACZNIAK, G. R. and Murphy, P. E., Ethical Marketing Decisions: The Higher Road (Boston: Allyn and Bacon), 1993.

MASON, T., “The Importance of Being Ethical”, Marketing, 2000, pp. 27.

MAYO, M. A., and Marks, L. J., “An Empirical Investigation of a General Theory of Marketing Ethics”, Journal of the Academy of Marketing Science, 18, 1990, pp. 163-171.

MCGOLDRICK, P. J. and Freestone, O. M., "Ethical Product Premiums: Antecedents and Extent of Consumers' Willingness to Pay", International Review of Retail, Distribution and Consumer Research, 18(2), 2008, pp. 185-201.

MINGQUAN, Z., Green Food Market Promises Bright Future, Market Trend, Available http://www.tdctrade.com/report/mkt/mkt_031002.htm. (13 October 2003).

MOISANDER, J., Representation of Green Consumerism: A Constructionist Critique, Helsinki School of Economics, Helsinki, a: 185, 2001.

MURPHY, P. E., Corporate ethics statements: An update, In Williams, O. F. (Ed). Global Codes of Conduct, Notre Dame, IN: University of Notre Dame Press, 2001, pp. 295-304.

MURPHY, P. E., Laczniak, G. R., Bowie, N. E. and Klein, T. A., Ethical Marketing, Upper Saddle River, NJ: Pearson Education, 2005.

MURRAY, K.B. and Vogel, C.M., "Using a Hierarchy-of-Effects Approach to Gauge the Effectiveness of Corporate Social Responsibility to Generate Goodwill toward the Firm: Financial Versus Nonfinancial Impacts" Journal of Business Research, 38(2), 1997, pp.141-159.

ÖZBEK, V., Alnıaçık, Ü. and Koç, F., “The Impact of Unfair Business Practices on Bank Customers: An Experimental Study”, Ege Academic Review, 12 (1), 2012, pp. 23-30.

QUAZI M. A., "Managerial Views of Consumerism: A Two Country Comparison", European Journal of Marketing, 36, (1/2), 2002, pp. 36-50. 
REIDENBACH, R. and Robin, D., "Toward the Development of a Multidimensional Scale for Improving Evaluations of Business Ethics", Journal of Business Ethics, 9(8), 1990, pp. 639-653.

ROBIN, D. P., and Reidenbach, R. E., "Social Responsibility, Ethics, and Marketing Strategy: Closing the Gaps between Concept and Application", Journal of Marketing, 51, 1987, pp.44-58.

SHERLAKER, S.A., Marketing Management, (6th ed). Himalaya Publishing House, 1999.

SHRUM, L.J., McCarty, J.A. and Lowrey, T.M., "Buyer Characteristics of the Green Consumer and Their Implications for Advertising Strategy", Journal of Advertising, 24(2), 1995, pp.71-90.

SINGHAPAKDI, A. and Vitell, S. J. "Marketing Ethics: Factors Influencing Perceptions of Ethical Problems and Alternatives.” Journal of Macro Marketing 10, 1990, pp. 4-18.

SINGHAPAKDI, A., "Perceived Importance of Ethics and Ethical Decisions in Marketing”, Journal of Business Research, 45(1), 1999, pp. 89-99.

SINGHAPAKDI, A., Vitell, S. J. and Kraft, K. L., "Moral Intensity and Ethical of Marketing Professionals Decision-Making”, Journal of Business Research 36,1996 , pp. 245-255

SMITH, N. C., "Changes in Corporate Practices in Response to Public Interest Advocacy and Actions". In Bloom, P.N., \& Gundlach, G.T. (Eds). Handbook of Marketing and Society, Thousand Oaks, CA: Sage Publications, 2001, pp. 140-161.

SMITH, N. C., Morality and the Market: Consumer Pressure for Corporate Accountability (London: Routledge), 1990.

STEINER, G. A., "Social Policies for Business." California Management Review, winter: 1972, pp. 17-24.

THONG, J.Y.L. and Yap, C., “Testing an Ethical Decision-Making Theory: The Case of Softlifting”, Journal of Management Information Systems, 15(1), 1998, pp. 213-237.

TSALIKIS, J. and Fritzsch, D., "Business Ethics: A Literature Review with a Focus on Marketing Ethics” Journal of Business Ethics, 8(2), 1989, pp. 695-743.

TSENG, H., Duan, C., Tung, H. and Kung, H., “Modern Business Ethics Research: Concepts, Theories, and Relationships" Journal of Business Ethics, 91(4), 2009, pp.587-597.

UUSITALO, O. and Oksanen, R., "Ethical consumerism - a view from Finland", International Journal of Consumer Studies, 28(3), 2004, pp. 214.

VITELL, S. J., Rallapalli, K. and Singhapakdi, A., "Marketing Norms: The Influences of Personal Moral Philosophies and Organizational Ethical Culture", Journal of the Academy of Marketing Science, (21), 1993, pp. 331-337. 